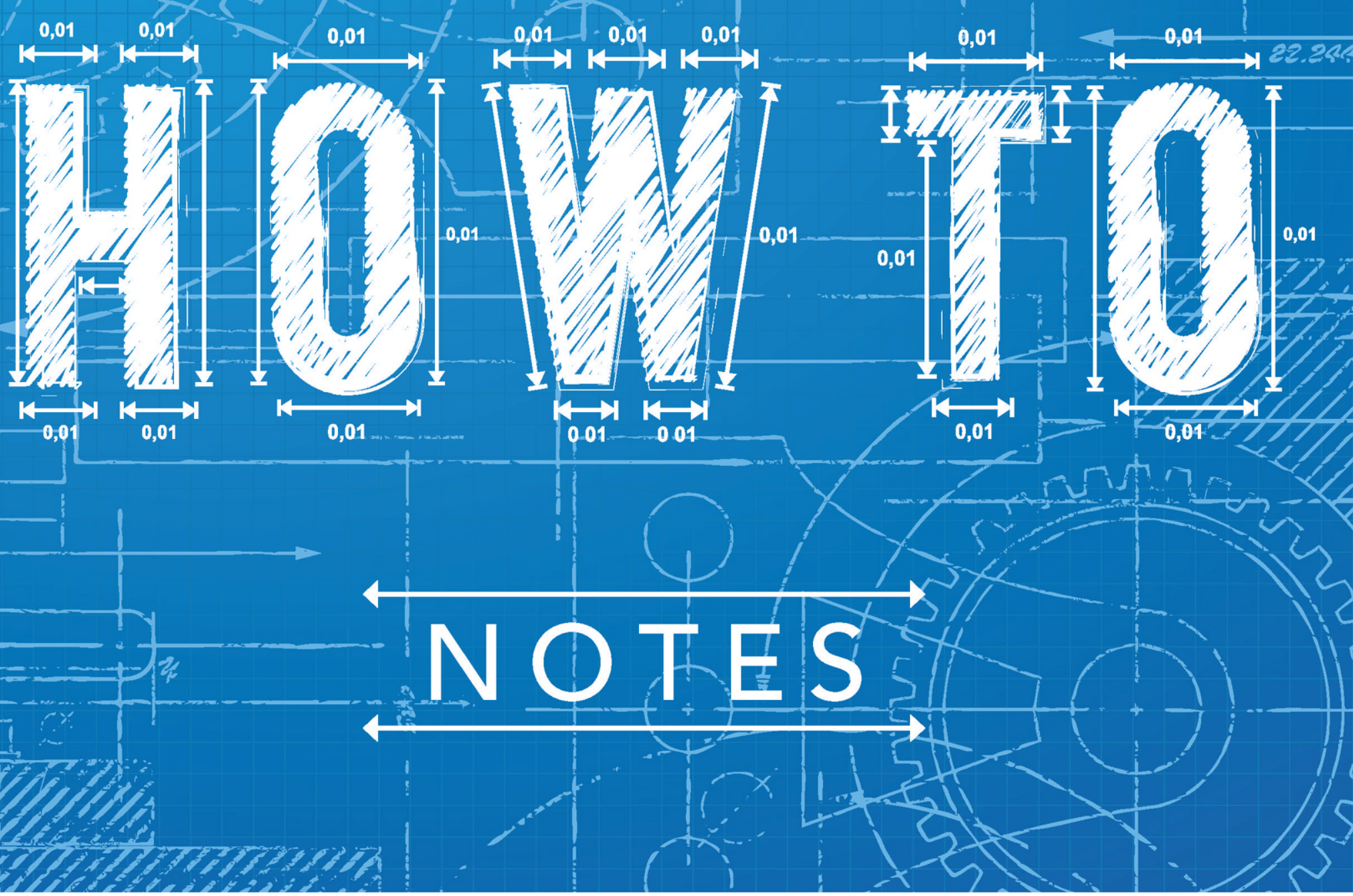

\title{
FISCAL POLICY
}

How to Adjust to a Large Fall in Commodity Prices 
0,01
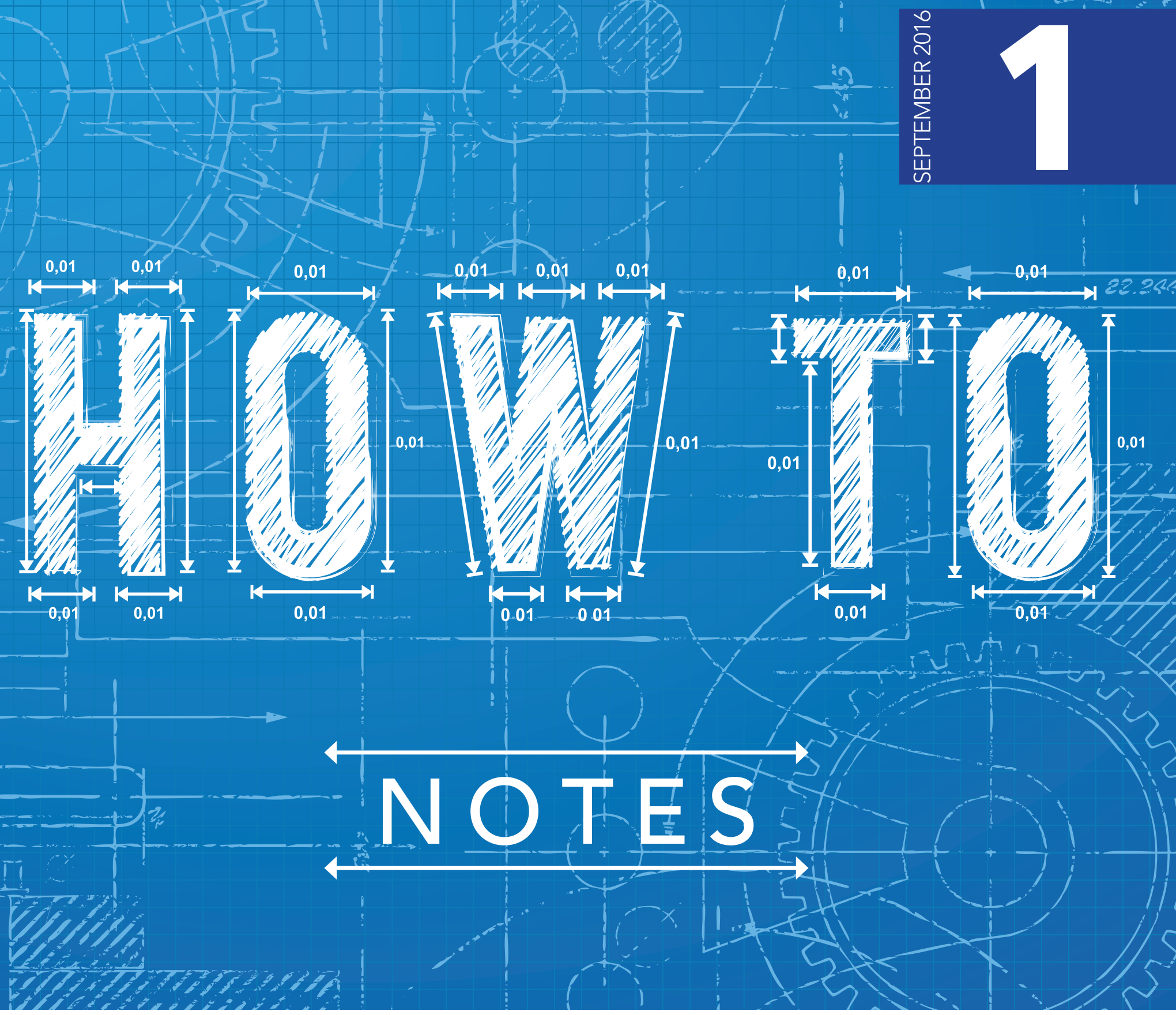

\section{FISCAL POLICY}

How to Adjust to a Large Fall in Commodity Prices 
(C)2016 International Monetary Fund

Cover Design: IMF Multimedia Services

Composition: AGS, an RR Donnelley Company

\section{Cataloging-in-Publication Data} Joint Bank-Fund Library

Names: Danforth, Jeff. | Medas, Paulo A. | Salins, Veronique. | International Monetary Fund. Fiscal Affairs Department.

Title: How to adjust to a large fall in commodity prices / prepared by Jeff Danforth, Paulo Medas, and Veronique Salins.

Other titles: Fiscal policy, how to adjust to a large fall in commodity prices | How to notes (International Monetary Fund) ; 1

Description: [Washington, DC] : Fiscal Affairs Department, International Monetary Fund, 2016. | How to notes / International Monetary Fund, ISSN nnnn-nnnx ; 1 | August 2016. | Includes bibliographic references.

Identifiers: ISBN 978

Subjects: LCSH: Commodity futures. | Prices. | Exports.

Classification: LCC HG6046.D35 2016

ISBN 978-1-47553-606-5 (paper)

DISCLAIMER: Fiscal Affairs Department (FAD) How-To Notes offer practical advice from IMF staff members to policymakers on important fiscal issues. The views expressed in FAD How-To Notes are those of the author(s) and do not necessarily represent the views of the IMF, its Executive Board, or IMF management

Publication orders may be placed online, by fax, or through the mail:

International Monetary Fund, Publication Services

PO Box 92780, Washington, DC 20090, U.S.A.

Tel.: (202) 623-7430 Fax: (202) 623-7201

Email: publications@imf.org

www.imf bookstore.org 
This page intentionally left blank 
Resource-rich countries have to manage highly volatile commodity revenues. In periods of revenue booms there is a tendency for large spending scale-ups. When facing large and persistent reductions in commodity prices, some of these countries will need to adjust their budgets to the new reality. In many cases, overall surpluses turn into large fiscal deficits and borrowing costs tend to rise with the fall in commodity prices. This note discusses how to undertake large fiscal adjustments, which often tend to be protracted and with long-lasting impacts on growth. Consequently, the note also highlights how to better prepare for future booms and busts in commodity prices.

\section{Challenges Facing Commodity Exporters}

Resource-rich economies face unique challenges associated with highly volatile revenues. Commodity prices fluctuate drastically and shocks can be large and persistent (Figure 1). Booms and busts, on average, involve prices moving by as much as $40-50$ percent (aluminum, iron ore) to 80 percent (natural gas, copper). Since resource-rich countries ${ }^{1}$ tend to rely heavily on commodity revenues to fund their budgets, price fluctuations can lead to procyclical movements in government spending. This volatility in expenditures can result in a destabilizing fiscal policy and undermine economic growth (IMF 2015a; Gelb and associates 1998; Van Der Ploeg and Poelhekke 2008).

A strong procyclical reaction during commodity price booms can lead to painful fiscal adjustments, with long periods of low economic growth, during price downturns. The large volatility in commodity prices poses unique challenges to medium-term fiscal planning and public financial management. During booms, there will be strong pressures to scale up spending independently of the capacity to manage it. This can lead to the need for large fiscal adjustments.

Prepared by Jeff Danforth, Paulo Medas, and Véronique Salins. ${ }^{1}$ Resource-rich economies are those countries where minerals (hydrocarbons and metals) account for a significant share of exports and/or fiscal revenues (IMF 2015a).
- During the 1970-80s booms, countries increased spending only to cut it dramatically during the subsequent busts. Real expenditures were reduced by more than a third between 1982 and 1988 in Ecuador, Iran, Libya, Peru, and Saudi Arabia, and many countries faced a long period of low or negative growth (Figures 2-4). For example, real GDP per capita declined by more than 4 percent per year in some countries between 1982 and 1988 (e.g. Nigeria and Saudi Arabia). Fiscal deficits remained sizable despite the expenditure cuts-e.g. they remained around 8-18 percent of GDP in several countries (Algeria, Nigeria, and UAE) in 1988.

- The sluggish recovery experienced by most resourcerich countries during the 1990s was further hindered by the commodity price shock associated with the Asian crisis of 1997-1998. Several countries had to cut expenditures significantly again leading to no growth in GDP per capita for nearly a decade (Libya, Saudi Arabia, Venezuela).

- The 2003-08 boom was followed by a sharp, but short lived, fall in commodity prices in 2008-09. In general, countries managed to smooth the shock thanks to their accumulated buffers, but expenditures were nevertheless significantly cut in many cases (Angola, Republic of Congo, Ecuador, Kuwait, Kazakhstan, Iran, Venezuela, Yemen).

- Many countries are facing the latest large, persistent fall in commodity prices with limited buffers leading to the need for large fiscal adjustments. In addition, economic growth has decelerated substantially.

This note discusses how to implement a fiscal adjustment when resource-rich countries are hit by a large and persistent fall in commodity prices. Most of the literature focuses on how to manage resource booms, including the best use for the abundant resources. However, little attention has been given on how to respond when a country becomes poorer due to lower commodity prices. The note discusses the key considerations on how to adjust the fiscal stance to the new budget constraints building on the IMF Fiscal Affairs Department's extensive research and technical assis- 
Figure 1. Real Commodity Prices

(U.S. dollars deflated by U.S. GDP deflators)

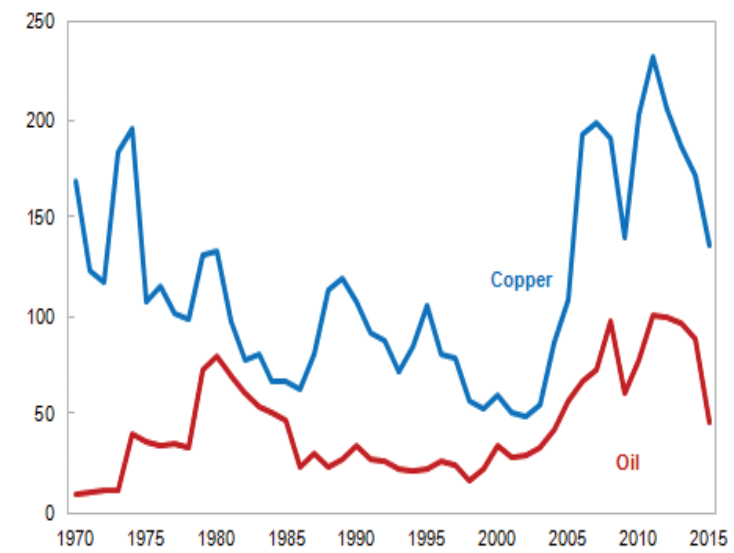

Source: IMF staff estimates.

Figure 3. Oil Producers: Real GDP Per Capita, 1970-99 $(1970=100)$

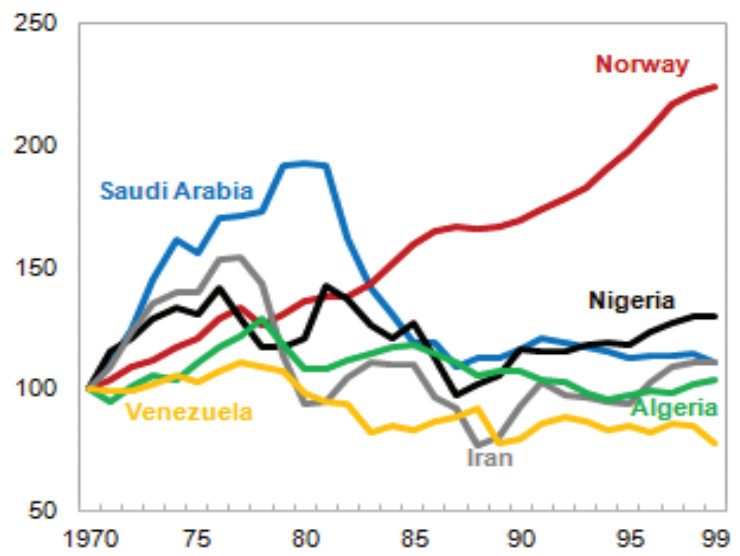

Source: IMF staff estimates.

tance. The next section discusses the overall strategy, followed by sections on the composition of the adjustment and the ways in which countries can prepare for the next boom and bust. Finally, an annex provides four country examples.

\section{Overall Strategy}

Resource-rich countries tend to be at a higher risk of having to undertake a large fiscal adjustment. Traditionally, fiscal adjustments are associated with macro stability and growth objectives (e.g. help contain inflation; external imbalance) and need to ensure the sustainability of the fiscal stance (IMF 1995). Resource-rich countries face additional challenges
Figure 2. Real Public Expenditure Growth For CommodityExporting Countries Before, During, and After Boom and Busts (Percent)

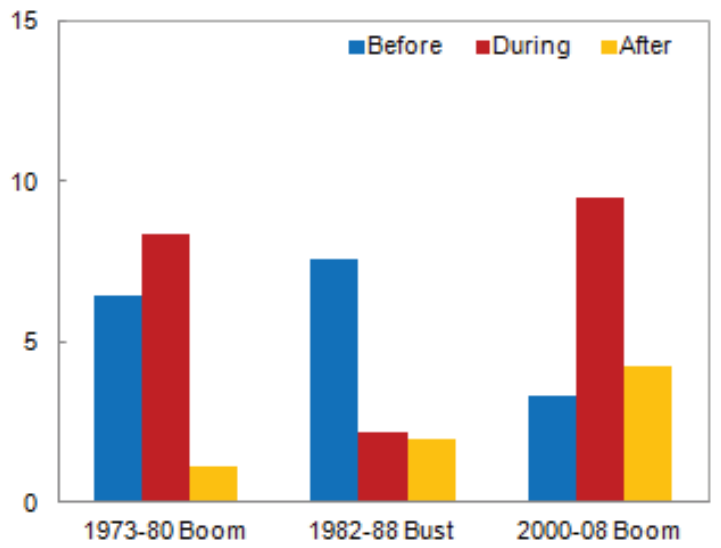

Source: IMF staff estimates.

Figure 4. Metal Exporters: Real GDP Per Capita, 1970-99 $(1970=100)$

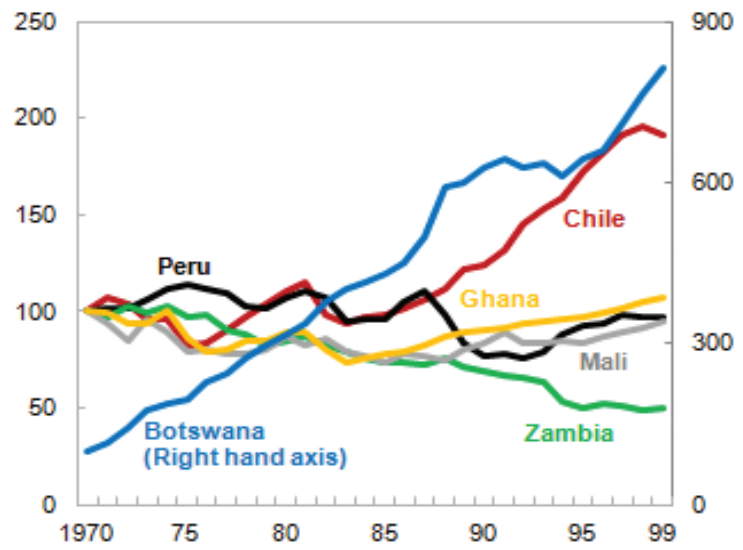

Source: IMF staff estimates.

due to the high uncertainty related to the valuation of resource wealth and the volatility of key resource revenue-making it complex to assess the appropriate fiscal stance. ${ }^{2}$ As illustrated above, and in the country cases in the annex, many countries do not build enough buffers to withstand large and persistent falls in prices: as economic rents accruing to the budget are

${ }^{2}$ Defining fiscal sustainability in resource-rich countries is a complex issue as it involves deciding how to smooth nonrenewable resource wealth over different generations under high uncertainty. IMF (2012) provides discussion of macro-fiscal frameworks for resource-rich developing countries, including sustainability issuesthe approach that was endorsed by the IMF Executive Board. IMF (2015a) and Van Der Ploeg (2013) discuss how to best address the uncertainty. 
significantly reduced, fiscal tightening is almost always inevitable. The pace and size of the adjustment will depend on several factors, including the magnitude of the commodity price fall, its impact on the budget, and the availability of buffers.

The adjustment should be set out in a medium-term fiscal strategy with clear objectives. The overarching objectives and policies needed to achieve them should be clearly established and well communicated. Social dialogue and broad political support enhance the likelihood of reforms being implemented and sustained (IMF 2015c). The strategy should include steps to achieve sustainable fiscal targets (e.g. nonresource fiscal balance) and identify the source of financing to smooth the adjustment process, where possible. ${ }^{3}$ Coverage of government should be broad to avoid shifting fiscal problems to other levels of government. Given that fiscal slippages can come from state-owned enterprises (SOEs), including national oil companies, expanding targets to the whole public sector is advisable.

Countries that are more dependent on commodity-related revenue will be more vulnerable to shocks. For example, oil exporters that tend to be the most dependent on resources experienced a massive shift from large budget surpluses, averaging $4 \frac{1}{2}$ percent of GDP in 2012, to deficits of 101/4 percent of GDP in 2015. In heavily commodity-dependent economies, large commodity price shocks can also trigger problems in other vulnerable sectors (e.g. financial system), which may require faster/larger adjustment to be able to manage contingent liabilities. Other resource-rich countries with more diversified economies and tax bases are better prepared to weather commodity-related shocks.

Countries with little or no buffers face hard policy choices when hit by a sudden fall in commodity prices. A large up-front fiscal adjustment will be needed for those countries that face large financing gaps, limited access to capital markets, or rapidly rising debt. ${ }^{4}$ Governments will likely turn to expenditures that are easier

\footnotetext{
${ }^{3}$ The strategy will depend on the specific country circumstances and will need to take into account short-term constraints (e.g. size of the financing gap), but also longer-term objectives. For example, targeting a sustainable level of nonresource (structural) fiscal balance as a share of nonresource GDP. However, the precise target will depend on country circumstances. See Medas and Zakharova (2009) and IMF (2015a) for further discussion.

${ }^{4}$ For example, a country highly dependent on resource revenue would need to have large net financial assets to withstand a shock without needing to start a fiscal adjustment, even as the economy is adjusting to the negative shock. Countries that can access capital markets may face high borrowing rates as they tend to be correlated with commodity prices in resource-rich countries.
}

Figure 5. Net Financial Assets Breakdown (2014)

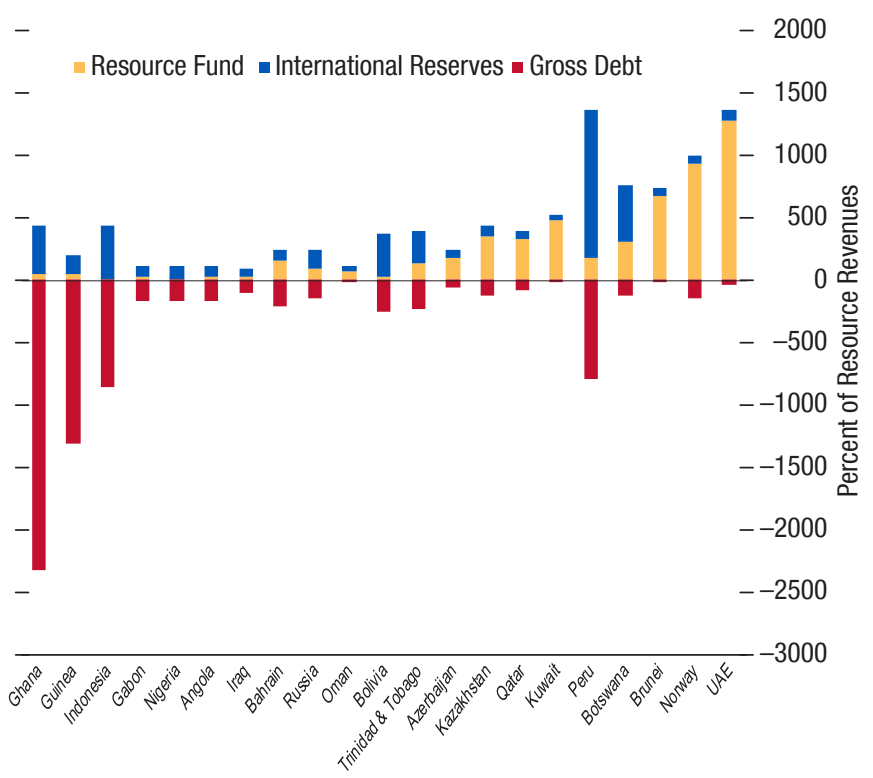

Source: IMF staff calculations based on International Financial Statistics, World Economic Outlook, and Sovereign Wealth Fund Institute data.

to cut or increase existing fees and taxes. This may unavoidably lead to a contraction of economic activity. To try to minimize it, the priority should be on measures that have low fiscal multipliers ${ }^{5}$ and address the excesses of the boom. For example, by postponing new spending initiatives, cutting low-quality projects and expenditures linked to imports, and expanding tax bases. Low-income countries will likely need to rely on greater donor and international financial institution support while gradually adjusting.

Countries with fiscal buffers can focus on a smoother, progrowth adjustment process. Even countries with sizable buffers may need to undertake significant (gradual) adjustments as fiscal deficits become too large to sustain over the medium term. For example, only a few countries (e.g. Norway and UAE) faced the 2014-15 fall in oil prices with large enough buffers to shield the budget to a high degree (Figure 5). Several countries (e.g. Algeria, Kazakhstan, Oman, Saudi Arabia) are all expected to turn from net creditors to large net debtors over the next years if no

\footnotetext{
${ }^{5}$ The estimated size of fiscal of multipliers in the literature varies significantly across countries/studies (e.g. some find as low as zero in Peru to 2.7 in Malaysia). Nevertheless, empirical findings suggest that government investment is associated with larger multipliers than government consumption in developing countries. The evidence is more mixed in emerging market and advanced economies. An increase in property taxes, on the other hand, seems to be the most growth-friendly instrument (Batini and others 2014).
} 
fiscal adjustment is done. Still, sizable buffers allow these countries to consolidate at a slower pace, protect priority areas, and focus on reforms of higher quality. The speed of the adjustment will need to take into account the impact on growth (e.g. fiscal multipliers) and the need to converge to a sustainable debt position. The choice between drawing down financial assets and borrowing will depend on the portfolio of assets, its respective returns, the cost of borrowing, and management of risks and trade-offs between the different assets and liabilities (e.g. domestic versus external borrowing). ${ }^{6}$

Strong fiscal institutions are needed to help achieve and sustain the fiscal adjustment. In particular, in many countries, this will include a need to strengthen public financial management (PFM). Effective expenditure controls are critical to implement the fiscal adjustment, but also to ensure fiscal discipline and implementation of sound fiscal policy (Pattanayak 2016). A key challenge that many countries face is the emergence of expenditure arrears, which may be unavoidable in countries that face acute liquidity constraints (as resource revenues fall sharply) and have ongoing projects/spending obligations. Arrears also tend to result from weak expenditure controls and inefficient cash management. ${ }^{7}$ In these cases, a comprehensive, transparent and credible strategy should be designed to address the accumulation of arrears and clear the outstanding stock (Flynn and Pessoa 2014). ${ }^{8}$ In some resource-rich countries there is also a need to strengthen the macro-fiscal functions in order to prepare a credible medium-term fiscal strategy and strengthen fiscal risk management.

Adjustments undertaken through fiscal policy action should be considered within the wider macro-financial context. A flexible exchange rate has been found to mitigate growth losses after a shock (IMF 2016a) and a depreciation of the currency could help with the adjustment process. However, it is important that robust monetary policy frameworks and well-developed monetary and foreign exchange markets are in place

\footnotetext{
${ }^{6}$ Annex 2 of IMF 2016b elaborates on some of these trade-offs. ${ }^{7}$ Expenditure arrears can also result from other failures at any or all stages of the PFM cycle, including inadequate legal frameworks, unrealistic budgeting, lack of or problems with a financial management information system, or gaps in fiscal reporting.

${ }^{8}$ This strategy should communicate to stakeholders the government's plan, timetable, and criteria for the liquidation of arrears. It should apply to all outstanding payments incurred by all parts of the public sector (including state-owned enterprises) and include measures to avoid the accumulation of new arrears.
}

to mitigate potential risks, including higher inflation and deteriorating balance sheets. ${ }^{9}$ For countries that are highly undiversified, preserving a peg can provide a helpful anchor for policymakers but only if large financial buffers exist and/or credible fiscal adjustments are possible in the face of persistent shocks (IMF 2016b; Husain and others 2015). Large swings in commodity prices can lead to deteriorations in household and corporate balance sheets with negative spillovers into the finance and banking sectors potentially affecting the fiscal adjustment. Appropriately coordinated macro-financial policies can help mitigate financial sector vulnerabilities and their fiscal consequences. Moreover, when monetary and fiscal policies are well coordinated, a credible fiscal adjustment may allow monetary easing to support economic activity. ${ }^{10}$

Limiting the negative impact of the fiscal adjustment on non-resource sector growth and competitiveness is an important element of the strategy. The design of the fiscal adjustment and accompanying structural reforms can help protect to some extent the non-resource sector and promote economic diversification.

- Growth-friendly measures. Measures that have a negative impact on the business environment (e.g. distortionary fees) should be avoided as much as possible. Given that real public wages tend to be high in some resource-rich countries, a policy to contain or reduce them could be helpful for competitiveness, especially if the private sector wage setting process uses the public sector as a reference (IMF 2016c).

- Structural reforms. One key objective will be to promote a larger and more competitive non-resource tradable sector. The adjustment should be accompanied by efforts to improve the business environment, including by enhancing the quality of institutions and governance, which tends to be weaker in resource-rich countries (IMF 2015a). Measures to increase the flexibility of the labor market, including increases in labor force participation and internal competition, and fiscal reforms to promote growth (e.g. well-targeted R\&D tax incentives; see IMF 2015c) could also be considered as needed. ${ }^{11}$

The fiscal adjustment and implementation of structural reforms should be accompanied by strength-

\footnotetext{
${ }^{9}$ See country studies on Chile and Nigeria for potential impacts of exchange rate depreciations.

${ }^{10} \mathrm{At}$ the same time countries should avoid monetization of the fiscal deficit.

${ }^{11}$ See the Chile case in the annex for structural reforms aiming at strengthening competitiveness.
} 
ening safety nets to protect the most vulnerable. This should include targeted cash transfers to compensate only lower-income groups for the impact of reforms or targeted and productive public spending aimed at building physical and human capital. Countries can also focus on existing programs that can be expanded quickly, possibly with some improvements in effectiveness (such as school meals, public works, and reduction in education and health care user fees).

\section{Composition of the Fiscal Adjustment}

Different adjustment strategies may be feasible depending on the desired size of adjustment and country-specific circumstances.

- A careful review of the size and efficiency of all spending components will likely be necessary. In some countries, public expenditures account for more than two-thirds of the non-resource economy making them a ripe target for cuts. In some cases, the fiscal adjustment could involve a major rethinking of the size and functions of the state.

- Fiscal adjustments with a strong revenue enhancement component can also be an option, as many resource-rich countries have low non-commodity revenues reflecting the absence of taxes in some cases and low collection efforts.

\section{Expenditure Policy}

Streamlining public investment will likely need to be a component of the fiscal adjustment in many resource-rich countries. Resource-rich countries tend to scale up investment during booms. For example, during recent periods of high commodity prices, public investment tends to grow at a strong pace and to levels above other countries (Figure 6). However, evidence suggests that in many cases such large scaling up of investment involved poor-quality projects and low efficiency with little impact on growth (IMF 2015a). In addition, the size of investment may not be sustainable under new budget constraints. Therefore, cuts in public investment could be appropriate and may have limited impact on domestic activity (given a large import component) and long-term economic growth if efficiency is low. ${ }^{12}$ In this context, countries should prioritize efficient investment projects and avoid cut-

\footnotetext{
${ }^{12}$ For example, countries can review investment projects to reduce costs while achieving the same growth-enhancing objectives.
}

\section{Figure 6. Capital Expenditures Are Higher In Resource-Rich Countries During Commodity Booms (Percent of GDP)}

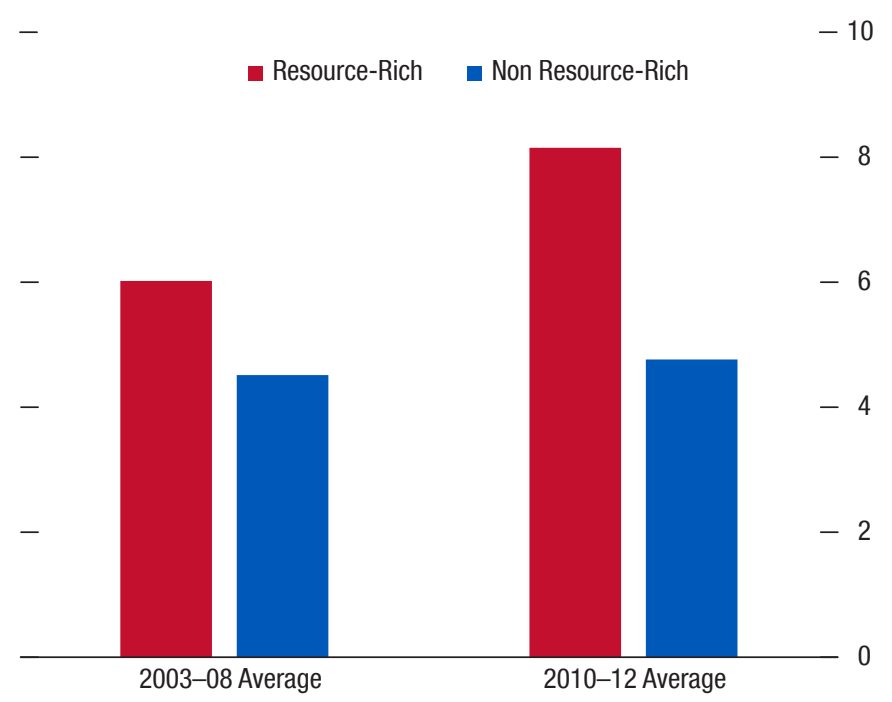

Source: WEO

ting investments with large positive impact on growth or significant social benefits as much as possible.

The cuts should be accompanied by efforts to enhance the efficiency of public investment. The degree of investment efficiency is key in determining the growth impact of public infrastructure (Gupta and others 2014; October 2014 World Economic Outlook). Several studies have pointed to weaknesses in public investment management. Dabla-Norris and others (2011) find that on average oil exporters tend to perform worse than others in terms of public investment management. In particular, they are found to have particularly low scores in the project appraisal and evaluation stages. Albino-War and others (2014) find that public investment management in oil exporters in the MENA region lags behind the most efficient international performers in all areas. They identify particular weakness at the appraisal and selection stages. ${ }^{13} \mathrm{By}$ strengthening public investment management practices countries could close up to two-thirds of the efficiency gap. The IMF's Fiscal Affairs Department (IMF 2015b)

\footnotetext{
${ }^{13}$ Suggested areas for improvement include cost-benefit analysis, at least for large projects; medium-term planning and budgeting frameworks integrated with the annual budget; selection of investments on the basis of relevant sector strategies; and consideration of recurrent costs. In Chile, for instance, a National Investment System (NIS) ensures appropriate management of public investment projects. As a result of close scrutiny of public projects, the road and health sectors started to generate costs savings in the 2000s.
} 
Figure 7. Public Wage Bill During Resource Booms (Average annual growth, percent)

-2003-08 $=2010-12$$$
-
$$

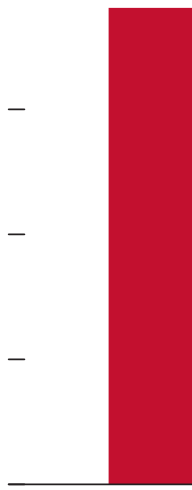

Resource-rich countries
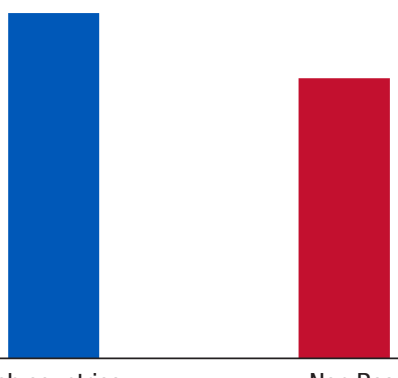

Non Resource-rich

Source: WEO

has developed a comprehensive framework to assess the quality of public investment management and identify the priorities for reforming it - the Public Investment Management Assessment (PIMA). ${ }^{14}$

In the short run, current expenditure cuts should focus on the larger spending items. Across-the-board cuts should be avoided since they are neither efficient nor welfare enhancing (IMF 2014). They can affect the economy's long-term growth potential and hurt low-income households. Typically, an area ripe for cuts is the wage bill, which tends to boom during periods of high commodity prices (Figure 7 ). Short-term measures can include a freeze on wages, streamlining of bonuses and allowances, and partial or selective hiring freezes. However, these measures are likely to only provide temporary relief.

Reforming public expenditures will likely require a comprehensive evaluation of the size and functions of the state and deeper institutional reforms. It is important to carry out an expenditure review that examines the role of government and the cost-effectiveness of different policy interventions which will help identify priority areas (e.g. on health or education) and eliminate others-e.g. reduce ill-targeted and costly transfers and subsidies. ${ }^{15}$ Functional reviews of government

\footnotetext{
${ }^{14}$ The public investment institutions of 11 countries have already been assessed with this methodology.

${ }^{15}$ This was the key component of the fiscal adjustment that took place in Canada in the 1990s (see annex).
}

departments can help inform structural reforms, including identifying areas of duplication and overlap. Countries should also implement institutional reforms that focus on weaknesses in the management of wage and employment processes (IMF 2016c). Structural reforms to target sectors with excessive employment and wage levels will also likely be needed to sustain the wage bill adjustment (e.g. strengthening human resource management, including through census of government employees, and public sector restructuring and outsourcing non-core functions).

Reform of domestic energy pricing can help the budget and contribute to greater efficiency in the economy. Resource-rich countries tend to have the largest energy subsidies - amounting to 10-50 percent of budgetary expenses in oil exporters during the recent boom (IMF 2015a). Even if the size of energy subsidies is smaller when prices are low, this is an opportune time to initiate the reforms as it mitigates the transition costs to firms and households and helps overcome public resistance. Lessons from country experiences (Clements and others 2013) highlight key elements of a reform: (1) a communication campaign, (2) phased and gradual price increases, (3) well-designed mitigation measures for households and firms (especially those that are heavily energy-intensive), (4) accompanying measures to improve the efficiency of SOEs and service delivery, and (5) introduction of an automatic pricing formula to reduce the chances of reform reversal. The last one is particularly important, given pressures to reverse the reforms during commodity booms, ${ }^{16}$ as the savings should be used to build fiscal buffers or for spending in other priority areas.

\section{Non-resource Revenues}

Increasing non-resource revenues should be part of the fiscal adjustment strategy, especially as they are critical to lowering the vulnerability of the budget to commodity prices. Countries would benefit from developing a well-designed tax system with larger tax collection from the non-resource sector and rents from the resource sector. ${ }^{17}$ This would not only help the budget, but also improve equity and further sup-

\footnotetext{
${ }^{16}$ In recent years, many oil exporters have increased domestic fuel prices, but without fully liberalizing or incorporating automatic price formulas. Once international prices rise, subsidies could once again increase.

${ }^{17}$ For example, introducing income taxes may help capture part of the oil sector rents that go to high wages.
} 
port accountability and civil society engagement. In countries where the resource sector is very large, raising substantial non-resource revenues will need to be complemented with efforts to diversify the economy.

Building better tax systems, however, requires time and effort. It requires substantial investments in building effective tax administrations and educating taxpayers on both the general need for, and precise nature of, changes in the tax system. In the Gulf Cooperation Council for instance, it is assumed that the planned introduction of a value-added tax (VAT) will likely take about two years. Important steps have to be taken including adapting the legislation, organizational adjustment, development of a communication strategy, and registration of taxpayers.

A well-designed tax system typically relies on a limited number of broad-based taxes.

- There is a considerable scope for boosting revenues from goods and services in resource-rich countries since they tend to collect only about half of what other countries do. Establishing a broad-based VAT could lead to substantial revenue mobilization and improve the efficiency of taxation-if properly designed and administered it does not affect investment decisions. Countries that have a VAT could consider rationalizing exemptions, broadening the base, reviewing the registration threshold, and raising rates. The number of tax exemptions should be limited to improve targeting and reduce their cost to the budgets. ${ }^{18}$ These reforms can be complemented by the introduction of selective excise taxes on goods that are likely to be the best sources of revenue (e.g. tobacco, alcohol or soft drinks).

- Another option involves expansion of direct taxes (some countries do not have them), including income and property taxation, which could increase tax revenues and improve equity. For those that already have personal income taxes, there is usually room to reduce tax exemptions, lower income thresholds, streamline allowances, and adopt a progressive tax rate structure. ${ }^{19}$

- On corporate income taxes, there is usually scope to adopt measures to protect the tax base such as eliminating tax holidays and streamlining deduc-

${ }^{18}$ In Angola, the estimated revenue loss due to the narrow tax base of the consumption tax and reduced rates for some products and services represents $2 \frac{1}{2}$ percent of GDP (IMF Country Report No. $15 / 302$, Selected Issues).

${ }^{19}$ See Jewell and others (2015) for a discussion of options to improve tax systems in Middle East and North Africa. tions and allowances, among others. Countries may also consider taxing capital gains when assets located in their territory are transferred. This can be done by defining, as a source of income, gains recognized by non-residents attributable directly or indirectly to immovable property located in the country.

- In many resource-rich countries there is also room to improve tax and customs administration. Key priorities include improving compliance with tax laws and revenue flows; improving staff skills and productivity; reducing the overall costs of tax administration; and developing an effective information technology system.

An excessive dependence on fees should be avoided. Many resource-rich countries rely heavily on fees and stamps as a source of revenue. In 2012, they represented about 10 percent of total revenues raised by MENA oil exporters (Mansour 2015). While they can generate quick revenue gains, and may face little public opposition, they can be highly distortionary since the primary goal of fees is to regulate and rationalize access to certain public services. Moreover, they have limited revenue potential, are less transparent than taxes, increase budgetary rigidities, and undermine the business environment.

Privatization could play a role in the adjustment. Privatizing SOEs could improve the fiscal position in a given year by providing up-front resources (if the value of the company is positive) and/or removing persistent drains on the budget in cases where SOEs are loss-making. ${ }^{20}$ However, the impact of privatizations on long-term revenues is less clear. In cases where the SOE was paying dividends, revenues will be lower if not fully offset by higher corporate income taxes from newly privatized SOEs. In many resource-rich countries, there may be a need to balance the immediate funding requirements with other objectives for the privatization (e.g. help diversify the economy, increase productivity), which could take priority. In addition, privatizations can have short-term adverse impacts such as job losses and wage cuts, and higher prices for consumers. Such reforms should be accompanied with appropriate safety nets (Gupta and others 2001).

\footnotetext{
${ }^{20}$ The Malaysian case study in the annex provides an example of the potential benefits associated with privatization.
} 


\section{How to Ensure the Next Time Will Be Different?}

A well-designed fiscal framework that takes into account the large uncertainty can help improve fiscal management. Given that commodity resources are non-renewable, developing a long-term strategy can help avoid unsustainable policies and ensure greater intergenerational equity. Policies also need to take into account the high degree of uncertainty surrounding commodity revenues. The October 2015 Fiscal Monitor (IMF 2015a) discusses in detail how to strengthen fiscal frameworks in resource-rich countries to better manage the large uncertainty. In particular, since shocks can be highly persistent and involve disruptive fiscal adjustments there is a need for prudent policies and larger precautionary savings than in other countries. In addition, running overall fiscal surpluses (to accumulate net financial assets) during commodity booms is an important countercyclical tool and can help prevent "Dutch disease" effects. The decision on savings has to strike the right balance between accumulating financial assets and other investments (e.g. infrastructure, education). IMF (2012) provides a policy framework for developing resource-rich countries.

The approaches to estimate precautionary savings have varied in the literature and in practice. Typically there is a trade-off between accumulating a large buffer for future shocks and using resources for current needs, however, revenue windfalls diminish such tension. ${ }^{21}$ In some cases, the accumulation of buffers is linked to fiscal rules (e.g. Chile, Norway), but others do so without formal rules (e.g. Saudi Arabia, UAE, Kuwait). Different strategies have been proposed or implemented to build buffers:

- Reducing gross debt during the windfall in order to shield the budget by borrowing when prices fall. While desirable, this strategy may not be sufficient to weather long-lasting commodity price shocks. Moreover, it can be costly since the price of borrowing tends to be higher and access to capital markets more limited when price falls.

- Adopting "conservative" commodity prices assumptions in the annual budget or using averages of past and/or projections of future prices. This approach still involves significant volatility but would result in some degree of savings during a windfall.

${ }^{21}$ For example, many countries did save considerably during the 2003-2008 period while still enjoying robust economic growth (Algeria, Botswana, Chile, Kuwait, Kazakhstan, Saudi Arabia, UAE).
- Using a value-at-risk approach. Stabilization buffers are built based on an assessment of the volatility of commodity prices (IMF 2012). However, traditionally, this approach has focused on providing coverage for only a limited number of years — as self-insurance for longer periods has been considered too costly_with buffers likely to be depleted after a few years.

The latest period of turbulence in commodity prices highlights the benefits of precautionary buffers that account for the high degree of long-term uncertainty. Recent history suggests many resource-rich countries have limited buffers to cushion against large and persistent shocks. One exception is Norway, which has a high degree of self-insurance and has delinked annual budgets from commodity prices. But, even a less conservative approach could provide more long-lasting financial buffers. ${ }^{22}$ Governments could accumulate financial buffers, during booms, such that the returns would be used to protect the budget from most shocks. The buffer could be partially depleted in response to more extreme shocks and allow for a gradual adjustment. The size of precautionary buffers would depend on different factors, including the dependence on resource revenues and the degree of risk aversion (IMF 2015a).

Fiscal policy, structural reforms, and economic diversification can help contain the impact of commodity price booms and busts. The tax, expenditure, and structural reforms discussed in the previous section, if adopted during the boom, can improve resilience (helping better manage the bust). In particular reforms that improve public financial management can ensure quality spending, and a diversified economy and tax base reduce reliance on volatile resource-sector revenues. ${ }^{23}$ Fiscal regimes for extractive industries can also be designed to strike a balance between limiting the volatility of government revenue and ensuring an appropriate share of the resource wealth for the government. Ensuring sufficient transparency in each aspect of the policy framework can improve adherence.

\footnotetext{
${ }^{22}$ See, for example, Van Der Ploeg (2013). Cherif and Hasanov (2013) estimate that the precautionary savings rate is sizable (around 30 percent of income) for oil exporters given high (persistent) shocks to oil revenues.

${ }^{23}$ In countries where the resource sector represents a large share of the fiscal revenues (Equatorial Guinea, Azerbaijan, Kuwait, Qatar, Saudi Arabia), mitigating the volatility of revenues necessarily implies focusing on the development of the non-resource sector. This is a long and difficult process (Callen and others 2014).
} 


\section{Annex: Country Experiences}

\section{Chilean Adjustment 1982-1988: Preserving the Country's Competitiveness}

A sharp drop in world copper prices, rising interest rates, and significant real appreciation of the peso led to a massive economic recession in Chile in the early 1980s. Economic growth declined sharply from 5.3 percent in 1981 to -14 percent in 1982 . The fiscal balance turned from a surplus of 5.5 percent of GDP in 1982 to a deficit of 3.4 percent in 1982 as revenues collapsed. The exchange rate peg was abandoned and capital outflow controls were imposed as international reserves were depleted. The sharp depreciation led to a deterioration of the balance sheet of the private sector, which was heavily externally indebted. The unemployment rate rose from 8.5 percent in 1981 to 24 percent by the end of 1982 and the financial system became highly vulnerable. In this context, the authorities began an ambitious fiscal adjustment supported by two consecutive IMF programs. A key objective was preserving the country's competitiveness.

The fiscal adjustment included the following measures:

- Tax measures. The authorities increased taxes on tobacco products, imposed temporary surcharges on personal income and real estate, introduced a gambling tax, and raised the automobile road tax by 60 percent for one year. The import tariffs were temporarily increased initially, but this policy was reversed in 1985 in an effort to preserve the country's competitiveness and to contain inflation. Successive measures included the broadening of the VAT coverage and an increase in the rate of taxes on luxury goods and property. In 1986 income tax was reformed by lowering tax rates for enterprises and individuals and providing tax benefits for reinvestment of earnings.

- Spending measures. The authorities successfully managed to reduce current expenditures, especially the wage bill. In 1982, wage indexation of public and private wages was abolished and the wage floor for collective bargaining was lowered. Moreover, the salaries of higher-paid employees of the public sector were cut by 10 percent and wage increases in the public sector were kept below inflation throughout the adjustment period. Public current expenditures declined from around 32 percent of GDP in 1982 to 26 percent in 1987.

- Structural reforms. The fiscal adjustment program was accompanied by a broad set of structural reforms aimed at (i) reducing the size of the state and liberalizing the economy, (ii) strengthening the tax system, and (iii) safeguarding the financial system. They included, in particular, the privatization of the social security system and of several public enterprises, the progressive liberalization of the exchange and trade system, adoption of a liberal foreign investment code, the simplification of personal and income taxes, and the recapitalization of financial institutions.

The successful large fiscal adjustment was supported by strengthening fiscal institutions. The fiscal deficit of 3.4 percent of GDP in 1982 turned to a surplus of 1.1 percent of GDP in 1988. Real GDP recovered in 1984 with an annual growth of 6.3 percent climbing to 7.4 percent by 1988 . These efforts were also reinforced by continuous improvement of the fiscal framework over the next decades, including introduction of a resource fund, and, later, a structural fiscal balance rule, and buildup of precautionary savings. This enabled the authorities to implement countercyclical fiscal policies during commodity price shocks and smoothed economic growth.

\section{Nigerian Adjustment (1982-1990): From Trade Restrictions to Economic Liberalization}

The significant drop in oil prices in 1981-82 led to sharp decline in oil revenues and exports (export volumes declined by more than 25 percent). Due to the delayed adjustment in imports, the current account deficit balance deteriorated from a surplus of about 5 percent of GDP in 1980 to a deficit of about 10 percent in 1982. International reserves were reduced to very low levels by 1982 . The authorities initially implemented trade restrictions through fiscal and administrative measures to reduce the external deficit and raise custom revenues. This policy was abandoned in 1986 when efforts to liberalize the economy were initiated.

Trade restrictions and large capital spending cut (1982-86). The initial reaction to the growing current account deficit was a series of fiscal and trade measures to limit imports.

- Large increases in tariffs were accompanied by the reintroduction of an advance import deposit scheme (to as much 250 percent for luxury goods), the broadening of the coverage of items subject to import licensing or prohibition and the tightening of administrative controls on imports. Capital controls were also tightened. 
Annex Figure 1. Fiscal Adjustments in Chile (1982-88)

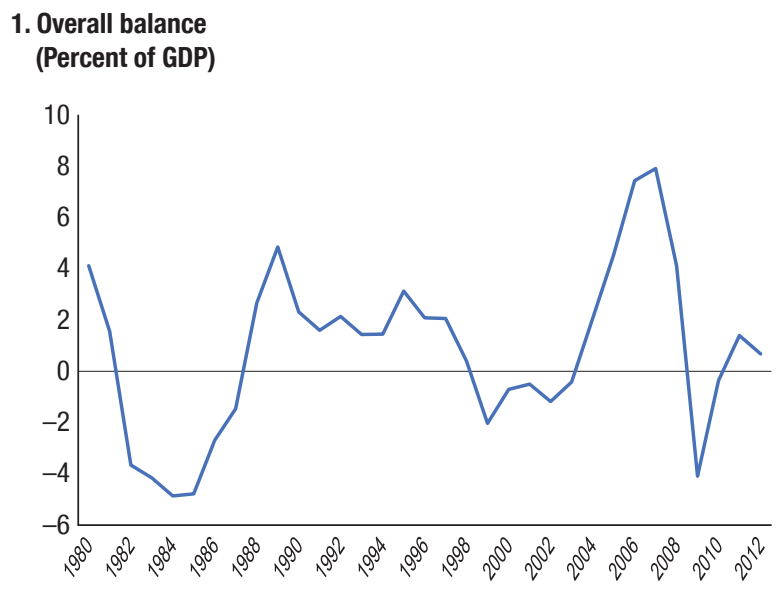

\section{Capital and Current Expenditures} (Percent of GDP)

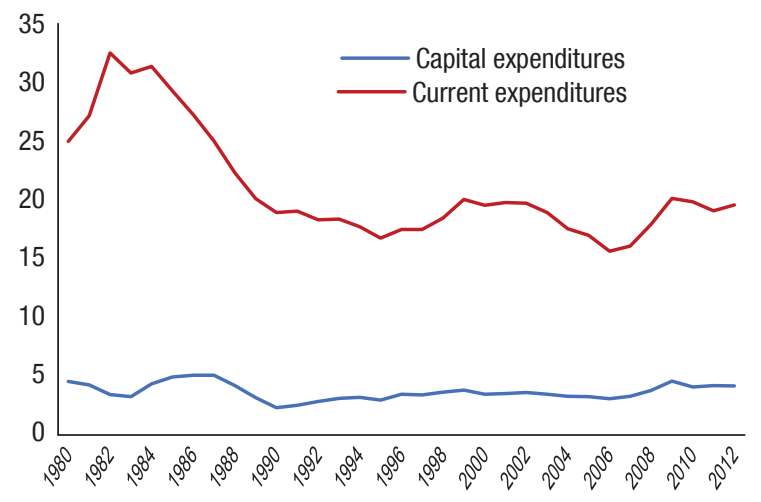

Source: IMF staff estimates.

- On the spending side, capital expenditures that had grown tremendously during the oil boom were significantly reduced. Their share fell to 41 percent in 1983, from 62 percent of the federal government expenditures in 1981-82-they were further reduced by half in 1984 . Current expenditures, on the other hand, kept growing due to large interest payments, increased transfers to state governments to help finance their deficits and subventions to the SOEs and public entities to help cover their losses. Fiscal discipline was eroded and the federal government's overall fiscal deficit averaged 6.5 percent of GDP from 1982 to 1985.

- The fiscal deficit was largely financed by the domestic banking system leading to a rapid growth of net domestic assets of domestic banks and to inflationary pressures. These pressures were

\section{Total Revenues and Total Expenditures (Percent of GDP)}

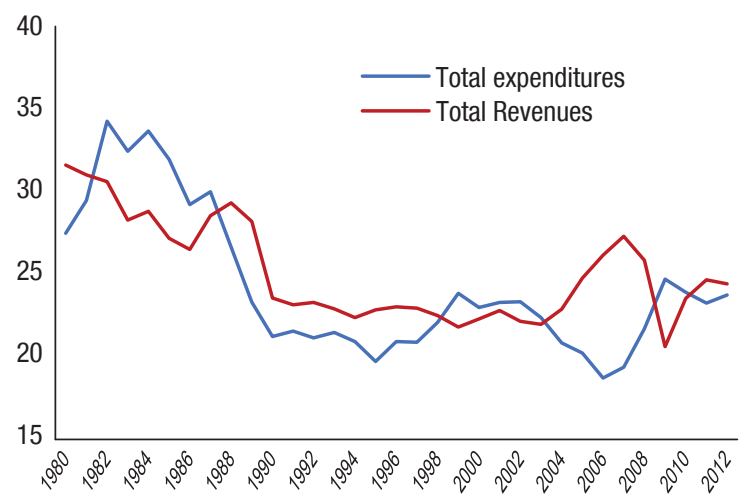

\section{Real GDP per capita (Index, 1980=100)}

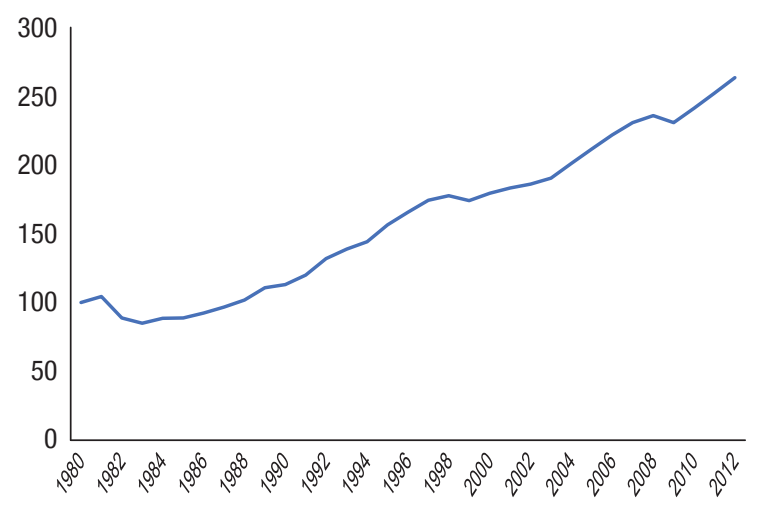

reinforced by shortages of imported consumer goods. While the nominal exchange rate remained relatively constant due to a policy of gradual depreciation of the naira against a basket of seven currencies, the real effective exchange rate increased steadily. Production continued to weaken ${ }^{24}$ as the sharp reduction in imports and increasingly complex regulations governing external trade began to cause disruption in economic activity and underutilization of productive capacity.

Structural adjustment efforts (1986-90). The abrupt decline in oil prices and oil revenues in 1985 exacerbated the country's difficulties leading the authorities

\footnotetext{
${ }^{24}$ Real GDP decreased on average by 3.7 percent per year from 1982 to 1985
} 
to adopt a comprehensive and radical program to resolve them the following year. In particular:

- They adopted a market-determined exchange rate system through the debut of a Second-Tier Foreign Exchange Market covering all transactions. An official (first-tier) exchange rate was initially maintained for foreign debt obligations but the two rates were unified during the following years.

- Import licensing was eliminated, such as export duties and most export licenses. Most price controls were also abolished.

- On the fiscal side, policies to improve the overall allocation of public expenditure were implemented. Moreover, authorities put considerable emphasis on the rationalization of states' fiscal positions. The size of the public sector was reduced through the commercialization and privatization of several SOEs. The initial results of the program were mixed. The large depreciation from exchange-rate liberalization led to an increase in oil revenue (in domestic currency) but dramatically raised the external public debt, which rose to more than 100 percent of GDP in 1986 leading to a sharp increase of the external debt service. The effects of the depreciation and more relaxed fiscal policy stance in 1987 and 1988 (the overall fiscal deficit reached 13.5 percent of GDP in $1988^{25}$ ) led to a sharp rise in inflation with an average rate of 37 percent per year between 1987 and 1989. However, Nigeria's economic performance improved between 1988 and 1990 with an average real GDP growth of 8.4 percent per year due to the strengthening of the country's competitiveness and rising oil prices. The authorities managed to reduce the fiscal deficit to 2.9 percent of GDP in 1990 but the fiscal policy remained procyclical during the 1990s and most of the 2000s. As a result, the country faces the recent drop in oil prices with very limited buffers.

\section{Canada: Taming the Deficits and Reducing Debt}

In 1993, when a new federal government was elected, Canada was recovering from recession and facing a large fiscal deficit. The fiscal situation of the federal government had also deteriorated over the preceding years. The overall deficit was higher than 5 percent of GDP in 1992 and 1993, the interest bill was nearly 30 percent of expenditures and debt was 65 percent of GDP. In 1995, the Wall Street Journal declared Canada an "an honorary member of the Third

\footnotetext{
${ }^{25}$ Source: IMF Staff Report for the 1992 Article IV consultation.
}

World" and referred to the Canadian dollar as the northern peso.

The government began a period of fiscal tightening with the 1994 budget. The target was a $31 / 2$ percent of GDP reduction in the overall deficit for 1993/94-1995/96 with 0.4 percentage point of GDP coming from tax increases and 3 percentage points from expenditure reductions. Tax measures included higher excises and corporate income tax rates, and the broadening of both personal and corporate income tax bases. Expenditure cuts were widespread and included wages, employment, unemployment insurance, and agricultural and business subsidies. The public service was reduced by nearly 45,000 positions over a two-year period. Key components of the adjustment process were the identification of a medium-term target (interim target of overall deficit of 3 percent of GDP in three years and balanced budget within five years) and the establishment of a contingency reserve. The finance minister briefed parliament on a semi-annual basis on progress being made in achieving the target, which helped improve public "buy-in" for the reforms.

The fiscal consolidation that took place over the 1993-2000 period improved the general government primary balance by 10 percentage points of GDP. The general government maintained a surplus through 2002, 8.5 percentage points above the initial 1993 position, despite a growth slowdown. Debt was reduced from 100 percent to 61 percent of GDP.

\section{Malaysia 1985-1990: Revitalization of the Private Sector}

A series of policy initiatives led to large deficits in the early 1980s, at a time when Malaysia had to manage the large fall in commodity prices. Large-scale development projects, such as launching a state-owned heavy industry sector, and other counter-cyclical fiscal policies aimed at offsetting the impact of the global recession in the early 1980s, pushed fiscal deficits to 17 percent of GDP by 1982. These policies became even more unsustainable after the sharp drop in the prices of Malaysia's major primary export commodities and the resulting recession.

By 1985 government debt had doubled, reaching 83 percent of GDP with SOEs accounting for 25 percent of GDP. Under the Fifth Malaysia Plans, which covered the period 1986-90, the government initiated a comprehensive reform package focused on reducing government expenditure and revitaliz- 
ing the private sector. Spending reforms included a freeze on public employment, a deferral of wage adjustments and a rationalization of non-essential capital expenditures. These reforms were accompanied by institutional changes aimed at improving strategic prioritization and devolution of decision making to line ministries.

Between 1986 and 1990 government expenditure fell by 9 percentage points of GDP (7 percentage points of which were current expenditures). Tax reforms sought to lower the tax burden and incentivize private investment. The excess profit tax was abolished, import duties on manufacturing sectors that had enjoyed tariff protection in the past were dismantled, corporate tax rates were reduced, and incentives such as tax holidays and targeted allowances were created. Revenue losses were offset by widening the sales tax base and improving revenue administration. The key element in the reform package was a widespread privatization and economic liberalization program. SOEs were restructured or liquidated and the proceeds were earmarked to pay down the debt. New laws were created that liberalized the regulatory framework and relaxed foreign investment rules.

The reforms put Malaysia on a rapid growth trajectory. Over the period from 1986 to 1997, growth averaged around 8 percent of GDP, private investment increased to 32 percent of GDP from 14 percent, real per capita income nearly doubled and poverty declined from 19 percent to 6 percent. 


\section{References}

Albino-War, M., S. Cerovic, F. Grigoli, J. Flores, J. Kapsoli, H. Qu, Y. Said, B. Shukurov, M. Sommer, and S. Yoon. 2014. "Making the Most of Public Investment in MENA and CCA Oil-Exporting Countries." IMF Staff Discussion Note 14/10, International Monetary Fund, Washington, DC.

Batini, N., L. Eyraud, L. Forni, and A. Weber. 2014. "Fiscal Multipliers and Use in Macroeconomic Projections." Technical Note, Fiscal Affairs Department, International Monetary Fund, Washington, DC.

Callen, T., R. Cherif, F. Hasanov, A. Hegazy, and P. Khandelwal. 2014. "Economic Diversification in the GCC: Past, Present, Future.” IMF Staff Discussion Note 14/12, International Monetary Fund, Washington, DC.

Cherif, R., and F. Hasanov. 2013. "Oil Exporters' Dilemma: How Much to Save and How Much to Invest." World Development 52: 120-31.

Clements, B., D. Coady, S. Fabrizio, S. Gupta, T. Alleyne, and C. Sdralevich, eds. 2013. Energy Subsidy Reform: Lessons and Implications. Washington, DC: International Monetary Fund.

Dabla-Norris, E., J. Brumby, A. Kyobe, Z. Mills, and C. Papageorgiou. 2011. "Investing in Public Investment: An Index of Public Investment Efficiency.” IMF Working Paper 11/37, International Monetary Fund, Washington, DC.

Flynn, S., and M. Pessoa. 2014. "Prevention and Management of Government Expenditure Arrears." Technical Note, Fiscal Affairs Department, International Monetary Fund, Washington, DC.

Gelb, A., and associates. 1998. Oil Windfalls: Blessing or Curse? Oxford: Oxford University Press.

Gupta, S., A. Kangur, C. Papageorgiou, and A. Wane. 2014, "Efficiency-Adjusted Public Capital and Growth." World Development 57: 164-78.

Gupta, S., C. Schiller, H. Ma, and E. Tiongson. 2001. "Privatization, Labor and Social Safety Nets." Journal of Economic Surveys 15 (5): 647-69.

Husain, A., K. Tazhibayeva, and A. Ter-Martirosyan. 2008. "Fiscal Policy and Economic Cycles in Oil-Exporting Economies.” IMF Working Paper 08/253, International Monetary Fund, Washington, DC.

Husain, A., R. Arezki, P. Breuer, V. Haksar, T. Helbling, P. Medas, and M. Sommer. 2015. "Global Implications of Lower Oil Prices.” IMF Staff Discussion Note 15/15, International Monetary Fund, Washington, DC.

International Monetary Fund (IMF). 1995. "Guidelines for Fiscal Adjustment.” Pamphlet Series 49, Fiscal Affairs Department, International Monetary Fund, Washington, DC.
2012. "Macroeconomic Policy Frameworks for Resource-Rich Developing Countries.” Policy Paper, International Monetary Fund, Washington, DC. http://www.imf.org/ external/np/pp/eng/2012/082412.pdf.

. 2014. Fiscal Monitor: Public Expenditure ReformMaking Difficult Choices. Washington, DC: International Monetary Fund, April.

- 2015a. Fiscal Monitor: The Commodities Rollercoaster-A Fiscal Framework for Uncertain Times. Washington: International Monetary Fund, October.

—. 2015b. "Making Public Investment More Efficient." International Monetary Fund, Washington, DC. http://www. imf.org/external/np/fad/publicinvestment/.

_. 2015c. "Fiscal Policy and Long-Term Growth." Policy Paper, International Monetary Fund, Washington, DC. http://www.imf.org/external/np/pp/eng/2015/042015.pdf.

_. 2016a. "Weathering the Commodity Price Slump." Chapter 2 in Regional Economic Outlook: Sub-Saharan Africa. Washington: International Monetary Fund, April.

- 2016b. Learning to Live with Cheaper Oil: Policy Adjustment in MENA and CCA Oil-Exporting Countries. Middle East and Central Asia Departmental Paper, International Monetary Fund, Washington, DC. https://www.imf.org/ external/pubs/ft/dp/2016/mcd1603.pdf.

- 2016c. "Managing Government Compensation and Employment-Institutions, Policies, and Reform Challenges." Policy Paper, International Monetary Fund, Washington, DC. https://www.imf.org/external/np/pp/eng/2016/040816a.pdf

Jewell, A., M. Mansour, P. Mitra, and C. Sdralevich. 2015.

"Fair Taxation in the Middle East and North Africa." IMF Staff Discussion Note 15/16, International Monetary Fund, Washington, DC.

Mansour, M., 2015. "Tax Policy in MENA Countries: Looking Back and Forward.” IMF Working Paper 15/98, International Monetary Fund, Washington, DC.

Medas, P., and D. Zakharova. 2009. "A Primer on Fiscal Analysis in Oil-Producing Countries.” IMF Working Paper 09/56, International Monetary Fund, Washington, DC.

Pattanayak, S. 2016. "Expenditure Control: Key Features, Stages, and Actors." Technical Note, Fiscal Affairs Department, International Monetary Fund, Washington, DC.

Van der Ploeg, F. 2013. "Guidelines for Exploiting Natural Resource Wealth." OxCarre Research Paper 128, Centre for the Analysis of Resource-Rich Economies, Oxford University, Oxford.

Van Der Ploeg, F., and S. Poelhekke. 2008. "Volatility and the Natural Resource Curse.” OxCarre Research Paper 3, Centre for the Analysis of Resource-Rich Economies, Oxford University, Oxford. 
(1) 